\title{
A gyermekkori elhízás népegészségügyi vonatkozásai
}

\section{Public health implications of childhood obesity}

\author{
Szerző: Kovács Viktória Anna $\square$ \\ Országos Gyógyszerészeti és Élelmezés-egészségügyi Intézet
}

Beküldve: 2018. 08. 14.

doi: $10.24365 /$ ef.v59i4.348

\begin{abstract}
Összefoglaló: Bár jelenleg a prevalencia stabilizálódni látszik, a gyermekkori elhízás előfordulása hazánkban igen magas, jelenleg minden negyedik gyermek túlsúlyos vagy elhízott. A kórképnek mind gyermekkorban, mind felnőttkorban súlyos szövődményei vannak, így népegészségügyi hatása és költségvonzata is jelentős. Sajnos a jelenlegi kezelési módszerek kevés eredményt tudnak felmutatni, így a hangsúlyt elsősorban a megelőzésre kell fektetni. Jelenleg az ajánlások komplex megközelítést és egyidejűleg több fronton induló beavatkozásokat javasolnak a hatékony megelőzés érdekében, mely elsősorban a káros környezeti tényezők kiküszöbölését célozza. Kulcsszavak: gyermek, túlsúly, elhízás, szövődmények, költségek
\end{abstract}

Summary: Although recent surveys suggest a plateau of the prevalence of childhood obesity, the overall levels remain disturbingly high and affects roughly every fourth child in Hungary. Obesity in childhood causes a wide range of serious complications both in children and in adults, and increases the risk of premature illness and death later in life, raising public-health concerns with a significant burden. Unfortunately, treatment for childhood obesity currently remains largely ineffective, thus emphasize should be placed on prevention efforts. To increase the effectiveness of actions, recent guidelines suggest complex integrated approaches and interventions targeting different risk factors and adverse environmental determinants in parallel.

Keywords: children, overweight, obesity, complications, burden

\section{PREVALENCIA}

Az elmúlt évtizedekben a gyermekkori elhízás előfordulási aránya drámai mértékben növekedett, mind a fejlődő, mind a fejlett országokban. ${ }^{1}$ Ennek eredményeként, még ha számos országban, így hazánkban is, az „elhízás járvány” tetőzni látszik, a prevalencia igen magas. ${ }^{2}$ Magyarországon a túlsúly, illetve elhízás kb. minden negyedik gyermeket érinti, a súlyos elhízás (testtömegindex $\geq$ mint $35 \mathrm{~kg} / \mathrm{m}^{2}$ ) előfordulási aránya pedig mintegy $2,5 \%{ }^{2}$ Ha ezeket az arányokat visszavetítjük a legutóbbi, 2011. évi népszámlálás eredményeire, akkor ez összesen kb. 460.000 túlsúlyos és mintegy 50.000 súlyosan elhízott gyermeket jelent. ${ }^{3}$
A gyermekkori elhízás nem egyformán érinti az egyes társadalmi rétegeket, valamint az előfordulása jelentős regionális különbségeket mutat. ${ }^{4}$ Azoknál a családoknál, ahol a szülők is túlsúlyosak, vagy a szülók alacsony iskolázottságúak, illetve rossz anyagi helyzetǔek, nagyobb eséllyel lesz a gyermek elhízott. ${ }^{5}$ Ami a területi egyenlőtlenségeket illeti, munkacsoportunk kétszer akkora elhízás prevalenciát talált hét éves gyermekek körében a Dél-dunántúli és az Észak-magyarországi régióban, mint Közép-Magyarországon. ${ }^{6}$ Ezek a magas előfordulási arányok, illetve egyenlőtlenségek tükrözik a felnőttkori tendenciákat. 


\section{RÖVID- ÉS HOSSZÚ TÁVÚ KÖVETKEZMÉNYEK}

A gyermekkori elhízásnak mind gyermekkorban, mind felnőttkorban következményei vannak. ${ }^{7}$ A túlsúly és elhízás már gyermekkorban aláássa a fizikai, szociális és pszichológiai jóllétet és ismert kockázati tényezője a felnőttkori elhízásnak, valamint számos krónikus, nem fertőző megbetegedésnek. Elhízott gyermekeknél az ún. 2-es típusú cukorbetegség kockázata 4,5-5,5-szeres, az asztma esélye kb. 25\%-kal nagyobb, mint normál súlyú kortársaiknál. ${ }^{8,9}$ Emellett gyakoribbak az ortopédiai problémák, a szorongás és a depresszió, valamint a túlsúlyos gyerekek fele, a túlsúlyos serdülők $80 \%$-a felnőttkorban is elhízott marad. ${ }^{10}$ Fontos tudni azonban, hogy amennyiben a túlsúlyos gyermek testsúlya rendeződik, a jövőben akkor is nagyobb esélye lesz a felnőttkori szív- és érrendszeri betegségekre, mint egy normál súlyú gyermeknek. ${ }^{11}$ Az elhízás ugyanis gyermek- és serdülókorban kedvezőtlen irányba változtatja a szív- és érrendszer stuktúráját és funkcióját. ${ }^{12}$ Ezért azok a gyermekek, akik túlsúlyosak, emelkedett cardiovasculáris kockázattal bírnak egész életükben, akkor is, ha később a tápláltsági állapotuk rendeződik. A Harvard Növekedési Vizsgálat, amely 55 éven át követte a résztvevőket, kétszeres szívinfarktus mortalitást talált azoknál, akik serdülőkorban túlsúlyosak voltak, függetlenül a felnőttkori testsúlytól. ${ }^{12}$ Egy angol tanulmány 57 éves utánkövetéssel hasonlóan magasabb összhalálozást valamint szív- és érrendszeri mortalitást írt le azoknál, akiknél gyermekkorban a testtömegindex meghaladta a 75 percentilis értéket. ${ }^{12}$

\section{NÉPEGÉSZSÉGÜGYI VONATKOZÁSOK}

A gyermekkori elhízás komoly népegészégügyi probléma, melynek megelőzése és kezelése a jelenlegi beavatkozások és módszerek mellett kevés eredményt tud felmutatni. ${ }^{13,14}$

Magyarországon az egyes krónikus betegségek előfordulásáról központi regiszter hiányában pontos adatokkal nem rendelkezünk. Célzott adatbázis elemzések (pl. OEP finanszírozási adatok), illetve kisebb regiszterek (pl. Hypertonia Regiszter) segítségével azonban jó közelítéssel lehet becsülni a gyakoriságot. Így tudjuk, hogy az elhízás legjelentősebb gyermekkorban kialakuló szövődményei a 2-es típusú cukorbetegség, a magas vérnyomás, a depresszió és a szorongás, már ma is népbetegségnek számítanak hazánkban. 60 év felett kb. minden ötödik magyar manifeszt 2-es típusú cukorbetegségben szenved, évente mintegy 30.000 új esetet diagnosztizálnak és 2014-ben 727.000, 2-es típusú diabeteszes beteg volt $(6,4 \%) .{ }^{15}$ A hypertonia előfordulása hazánkban egyenletesen emelkedik, 2015-ben a 8,3 millió felnőtt lakosból 3,5 millió szenvedett e kórképben. ${ }^{16} \mathrm{Az}$ életkor emelkedésével párhuzamosan az előfordulás gyakorisága egyre nagyobb, 65 év felett már meghaladja a $60 \%$-ot. ${ }^{17}$ A hypertóniás betegek eloszlása is jelentős területi különbségeket mutat, és hasonlóan a gyermekkori elhízás prevalenciájában talált régiós eloszláshoz a leginkább érintett két terület Dél-Dunántúl illetve Észak-Magyarország. ${ }^{17}$ A depresszió előfordulási arányára vonatkozó magyar közlemények nagy szórást mutatnak (12-37\%), de abban egyetértenek, hogy a depresszió egyike a leggyakoribb pszichiátriai betegségeknek, mely jelentősen behatárolja a beteg és családja jóllétét és napi életvitelét. ${ }^{18}$

\section{KÖLTSÉGTERHEK}

Figyelembe véve a várható élettartam növekedését, és ezzel párhuzamosan a lakosságon belül az idősek arányának emelkedését, illetve hogy 1975 és 2016 között a gyermekkori elhízás előfordulása világszerte tízszeresére nőtt, ${ }^{1}$ hatalmas ugrás várható a jövőben a 2-es típusú cukorbetegség, valamint a szív- és érrendszeri betegségek már most is magas előfordulási arányában és ezzel párhuzamosan az erre fordított költségekben.

Kempler és munkatársai közleménye alapján egy 2-es típusú cukorbeteg egy főre eső éves teljes egészségügyi ellátásának költsége hazánkban nagyjából 350.000 forint. ${ }^{15}$ Felszorozva ezt a fent említett prevalencia adatokkal, a 2-es típusú betegek ellátása évente jelenleg kb. 255 milliárd forintba kerül, ami már most is az éves egészségügyre fordított költségvetés kb. 17\%-a.

Könnyen belátható tehát, hogy a gyermekkori elhízás terén észlelt magas előfordulási arány, illetve a szövődmények prevalenciájában látott növekvő tendencia hatékony beavatkozás nélkül veszélyezteti a magyar egészségügyi ellátórendszer fenntarthatóságát. 


\section{JÖVŐBELI IRÁNYOK}

Figyelembe véve az állapot súlyosságát és a szövődmények kialakulásának magas kockázatát, az egészségügyi ellátórendszerek figyelme érthető módon a kórosan elhízott gyermekek számára kidolgozott kezelési stratégiákra irányul. Népegészségügyi szempontból azonban a jóval nagyobb esetszám miatt súlyosabb egészségügyi és gazdasági terhet jelentenek a kevésbé elhízott gyermekek, akik sokszor teljesen elkerülik az ellátórendszert. Ebben az esetben a sikeres beavatkozás gátjai a diagnózis hiánya mellett az inaktív életmódot és a szükségesnél magasabb kalória bevitelt propagáló és támogató környezeti, kulturális és gazdasági tényezők.

Az elmúlt pár évben számos nagysúlyú, a gyermekkori elhízás megelőzésére és kezelésére irányuló nemzetközi stratégia és ajánlás született. ${ }^{19,20}$ Ezen ajánlások közös eleme, hogy az eddigiekkel ellentétben többszintű, több támadáspontú beavatkozást javasolnak. Nyilvánvalóan ezen intervenciók alapja az összehangolt és jól megtervezett lépések sorozata, melyben az egyes szereplők (pl. döntéshozók, várostervezők, étterem tulajdonosok, iskolaigazgatók, szülők stb.) szorosan együttmúködnek a közösen meghatározott célok elérése érdekében.

Összefoglalva, a gyermekkori elhízás megelőzése terén talán már mutatkozik eredmény (lásd a prevalencia stagnálása), de nyilvánvaló, hogy a siker érdekében nem elégséges csak az egészségügy szereplőinek erőfeszítése, társadalmi méretû összefogásra van szükség.

\section{HIVATKOZÁSOK}

\footnotetext{
${ }^{1}$ NCD Risk Factor Collaboration (NCD-RisC). Worldwide trends in body-mass index, underweight, overweight, and obesity from 1975 to 2016: a pooled analysis of 2416 population-based measurement studies in 128.9 million children, adolescents, and adults. Lancet. 2017 Dec 16;390(10113):2627-2642.

2 Kovacs VA, Bakacs M, Kaposvari C, Illes E, Erdei G, Martos E, Breda J. Weight Status of 7-Year-Old Hungarian Children between 2010 and 2016 Using Different Classifications (COSI Hungary). Obes Facts. 2018;11(3):195-205.

${ }^{3}$ Népszámlálás 2011. http://www.ksh.hu/nepszamlalas/tablak_demografia (Elérve: 2018. 08. 14.).

${ }^{4}$ Lee H, Andrew M, Gebremariam A, Lumeng JC, Lee JM. Longitudinal associations between poverty and obesity from birth through adolescence. Am J Public Health 2014; 104:e70-e76.

${ }^{5}$ OECD (2010), Obesity and the Economics of Prevention: Fit not Fat, OECD Publishing, Paris, https://doi.org/10.1787/9789264084865-en

${ }^{6}$ Erdei G, Bakacs M, Illés É, Nagy B, Kaposvári C, Mák E, Nagy ES, Cserháti Z, Kovács VA. Substantial variation across geographic regions in the obesity prevalence among 6-8 years old Hungarian children (COSI Hungary 2016). BMC Public Health. 2018; 18(1):611.

${ }^{7}$ Word Health Organization. Obesity and overweight. http://www.who.int/en/news-room/fact-sheets/detail/obesityand-overweight (Elérve: 2018. 08. 14.).

${ }^{8}$ Abbasi A, Juszczyk D, van Jaarsveld CH, Gulliford MC. Body mass index and incident type 1 and type 2 diabetes in children and young adults: a retrospective cohort study. J Endocr Soc 2017; 1(5), 524-537.

${ }^{9}$ Granell R, Henderson AJ, Evans DM, Smith GD, Ness AR, Lewis S, Sterne JA. Effects of BMI, fat mass, and lean mass on asthma in childhood: a Mendelian randomization study. PLoS Medicine 2014; 11(7), e1001669.

${ }^{10}$ Word Health Organization. Why does childhood overweight and obesity matter? http://www.who.int/dietphysicalactivity/childhood_consequences/en/ (Elérve: 2018. 08. 14.).

${ }^{11}$ Bridger T. Childhood obesity and cardiovascular disease. Paediatrics \& Child Health 2009; 14(3), 177-182.

${ }^{12}$ Ayer J, Charakida M, Deanfield JE, Celermajer DS. Lifetime risk: childhood obesity and cardiovascular risk. Eur Heart J 2015; 36(22):1371-1376.

${ }^{13}$ Bautista-Castano I, Doreste J, Serra-Majem L. Effectiveness of interventions in the prevention of childhood obesity. Eur J Epidemiol 2004; 19(7): 617-622.
} 


\footnotetext{
${ }^{14}$ Bleich SN, Vercammen KA, Zatz LY, Frelier JM, Ebbeling CB, Peeters A. Interventions to prevent global childhood overweight and obesity: a systematic review. Lancet Diabetes Endocrinol. 2018 Apr;6(4):332-346.

${ }^{15}$ Kempler P, Putz Zs, Kiss Z, Wittmann I, Abonyi-Tóth Zs, Rokszin Gy, Jermendy Gy. A 2-es típusú diabetes előfordulása és költségterheinek alakulása Magyarországon 2001-2014 között - az Országos Egészségbiztosítási Pénztár adatbáziselemzésének eredményei. Diab Hung 2016; 24(3): 177-188.

${ }^{16}$ Blázovics A (2016). A Hypertonia Regiszter adatfelvétel-tanulságai. http://real.mtak.hu/38280/1/650.2016.26m.pdf (Elérve: 2018. 08. 14.).

17 Szegedi J, Kékes E, Sonkodi S, Kiss I. A hypertonia epidemiológiája Magyarországon. Hypertonia és nephrologia 2014; 18(5-6).

${ }^{18}$ Torzsa P, Rihmer Z, Gonda X, Sebestyén B, Szokontor D, Kalabay L. A depresszió prevalenciája az alapellátásben Magyarországon. Neuropsychopharmacologia Hungarica 2008, X/5, 265-270.

${ }^{19}$ European Union Action Plan on Childhood Obesity 2014-2020. Brussels: European Commission; 2014 http://ec.europa.eu/health//sites/health/files/nutrition_physical_activity/docs/childhoodobesity_actionplan_2014_2020_en.pdf (Elérve: 2018. 08. 14.).

${ }^{20}$ Report of the Commission on Ending Childhood Obesity. Geneva: World Health Organization; 2016 http://apps.who.int/iris/bitstream/10665/204176/1/9789241510066_eng.pdf (Elérve: 2018. 08. 14.).
} 